\title{
TOPICS IN PRODUCTION THEORY
}

This volume is devoted to current topics in production theory. The papers are organized under four headings. Part I deals with technical change. Jorgenson reports on econometric research on production functions for a large number of production sectors as part of a general equilibrium model of an economy. Forsund and Jansen focus on one industrial sector and study structural and technical change within the Norwegian aluminum industry, using Leif Johansens's concept of a short-run industry function. Kopp and Smith measure the effects of technical change on an even more disaggregated level. Two large-scale process analysis models provide a description of the production technology with the possibility of applying six specific process innovations. Baumol and Wolff outline a model which takes into account not only the contributions of $R \& D$ to the rate of growth of an economy's productivity, but also the likelihood that there is a relationship in the other direction.

Part II is devoted to efficiency. Diewert uses a comparative static framework and duality theory to characterize two measures of the loss to the economy brought about by distortions in the resource allocation in the production sector. Färe, Grosskopf and Lovell start out from Farrell's measure of productive efficiency and study nonparametric measurements of efficiency under less restrictive assumptions on technology.

The papers in Part III deal with aggregation, quasi-fixed factors and cost of adjustment. Epstein addresses the problem of aggregating quasi-fixed factors in the context of an adjustment-cost model. Blackorby and Schworm investigate the conditions under which - in adjustment-cost models aggregates for heterogeneous capital and investment exist for individual firms and the conditions under which the sum of wealth functions over firms depends only on aggregate capital. Pindyck and Rotemberg model the industrial demand for structures, equipment and blue- and white-collar labor in a manner consistent with rational expectations and stochastic dynamic optimization in the presence of adjustment costs. Brown and Greenberg investigate the conditions under which the Divisia index of total factor productivity for all production units is path independent within a general equilibrium framework.

Other aspects of production theory are present in Part IV. Vislie analyzes the optimal use of inputs for producing goods which take a long time to complete, when prices of inputs may change at some unknown future date. Bosworth and Pugh deal with the degree of capital utilization. In particular, increased utilization results in more rapid depreciation of the capital stock. Hamlin and Heathfield analyze consequences of the rate of profit being the maximand for a firm and examine ex ante employment, investment and shiftwork decisions in a putty-clay model when output and prices are given. Mizon and Nickell present estimates of a vintage production model for the U.K., with the aim of discovering whether it is possible to explain satisfactorily the output of manufacturing industries as a simple, stable function of a small number of input aggregates. 
Edited by Peter Bohm and Allen V. Kneese

THE ECONOMICS OF ENVIRONMENT

Edited by Jan Herin, Assar Lindbeck and Johan Myhrman

FLEXIBLE EXCHANGE RATES AND STABILIZATION POLICY

Edited by Steinar Strøm and Lars Werin

TOPICS IN DISEQUILIBRIUM ECONOMICS

Edited by Steinar Str $\phi \mathrm{m}$ and Björn Thalberg

THE THEORETICAL CONTRIBUTIONS OF KNUT WICKSELL

Edited by Steinar Str $\phi \mathrm{m}$

MEASUREMENT IN PUBLIC CHOICE

Edited by Lars Matthiessen and Steinar Strom

UNEMPLOYMENT: MACRO AND MICRO-ECONOMIC

EXPLANATIONS

Edited by Lars Matthiessen

THE IMPACT OF RISING OIL PRICES ON THE WORLD ECONOMY

Edited by Lars Calmfors

LONG-RUN EFFECTS OF SHORT-RUN STABILIZATION POLICY 


\title{
TOPICS IN PRODUCTION THEORY
}

\author{
Edited by
}

Finn R. Forsund

Department of Economics

University of Oslo, Norway

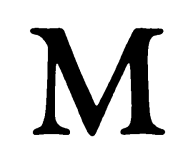

Palgrave Macmillan 
(C) The Scandinavian Journal of Economics, 1983, 1984

Softcover reprint of the hardcover 1st edition 1984 978-1-349-07123-4

All rights reserved. No part of this publication may be reproduced or transmitted, in any form or by any means, without permission

This collection was originally published in The Scandinavian Journal of Economics, Vol. 85, 1983, No. 2

First published in book form 1984 by

THE MACMILLAN PRESS LTD

London and Basingsioke

Companies and representatives

throughout the world

British Library Cataloguing in Publication Data Topics in production theory.

1. Industrial productivity

I. Førsund, Finn R.

$330 \quad$ HC260.I5Z

ISBN 978-0-333-36554-0 


\section{Contents}

Contributors' Affiliations vi

Part I Technical Change

Dale W. Jorgenson: Modeling Production for General Equilibrium Analysis

Finn R. F申rsund and Eilev S. Jansen: Technical Progress and Structural Change in the Norwegian Primary Aluminum Industry

Raymond Kopp and $V$. Kerry Smith: Neoclassical Modeling of Nonneutral Technological Change: An Experimental Appraisal

William J. Baumol and Edward Wolff: Feedback from Productivity Growth to R \& D

\section{Part II Efficiency}

$W$. Erwin Diewert: The Measurement of Waste within the Production Sector of an Open Economy

Rolf Färe, Shawna Grosskopf and C. A. Knox Lovell: The Structure of Technical Efficiency

Part III Aggregation, Quasi-fixed Factors and Cost of Adjustment

Larry G. Epstein: Aggregating Quasi-fixed Factors

Charles Blackorby and William Schworm: Aggregating Heterogeneous Capital Goods in Adjustment-cost Technologies

Roberg S. Pindyck and Julio J. Rotemberg: Dynamic Factor Demands under Rational Expectations

Murray Brown and Richard Greenberg: The Divisia Index of Technological Change, Path Independence and Endogenous Prices

\section{Part IV Other Aspects}

John Vislie: On the dynamics of Production under Cost Uncertainty

Derek Bosworth and Clive Pugh: Production and Maintenance; Joint Activities of the Firm

Alan Hamlin and David Heathfield: Shiftwork and the Choice of Technique under Alternative Maximands

Grayham Mizon and Stephen Nickell: Vintage Production Models of

U.K. Manufacturing Industry 


\section{Contributors' Affiliations}

Dale W. Jorgenson

Finn R. F申rsund

Eilev S. Jansen

Raymond Kopp

V. Kerry Smith

William J. Baumol

Edward Wolff

W, Erwin Diewert

Rolf Färe

Shawna Grosskopf

C. A. Knox Lovell

Larry G. Epstein

Charles Blackorby

William Schworm

Robert S. Pindyck

Julio J. Rotemberg

Murray Brown

Richard Greenberg

Jon Vislie

Derek Bosworth

Clive Pugh

Alan Hamlin

David Heathfield

Grayham Mizon

Stephen Nickell
Harvard University, Cambridge, MA

University of Oslo, Norway

Central Bureau of Statistics, Oslo, Norway

Resources for the Future, Washington, DC

University of North Carolina, Chapel Hill, NC

Princeton University, Princeton, NJ and New York University, NY

New York University, NY

University of British Columbia, Vancouver, BC

Southern Illinois University, Carbondale, IL

Southern Illinois University, Carbondale, IL

University of North Carolina, Chapel Hill, NC

University of Toronto, ON

University of British Columbia, Vancouver, BC

University of British Columbia, Vancouver, BC

M.I.T., Cambridge, MA

M.I.T., Cambridge, MA

State University of New York, Buffalo, NY

State University of New York, Buffalo, NY

University of Oslo, Norway

Loughborough University, Leicestershire, England

Loughborough University, Leicestershire, England

University of Southampton, England

Unversity of Southampton, England

University of Southampton, England

London School of Economics and Political Science, London, England 